\title{
Flight, feeding and reproductive behavior of Phyllophaga cuyabana (Moser) (Coleoptera: Melolonthidae) adults ${ }^{(1)}$
}

\author{
Lenita Jacob Oliveira(2) and Maria Alice Garcia(3)
}

\begin{abstract}
Phyllophaga cuyabana is a univoltine species and its development occurs completely underground. Its control by conventional methods, such as chemical and biological insecticides, is difficult, so it is important to understand its dispersion, reproduction, and population behavior in order to determine best pest management strategies. The objective of this work was to study the behavior of adults of $P$. cuyabana. This study was carried out in the laboratory, greenhouse and field sites in Paraná

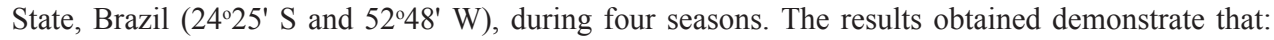
a) P. cuyabana adults have a synchronized short-flight period when mating and reproduction occurs; b) adults tend to aggregate in specific sites for mating; c) the majority of adults left the soil on alternate nights; d) the choice of mating and oviposition sites was made by females before copulation, since after copulation adults did not fly from or bury themselves at nearby locations; e) females that fed on leaves after mating, oviposited more eggs than females that had not fed; f) plant species such as sunflower (Helianthus annuus) and the Crotalaria juncea are important food sources for adults.
\end{abstract}

Index terms: Glycine max, white grub, host plants, oviposition, pests of plants.

Comportamento de vôo, de alimentação e de reprodução de adultos de Phyllophaga cuyabana (Moser) (Coleoptera: Melolonthidae)

\begin{abstract}
Resumo - Phyllophaga cuyabana é uma espécie univoltina cujo desenvolvimento ocorre no solo. Seu controle por inseticidas químicos e biológicos é difícil, assim é importante entender sua dispersão, reprodução e comportamento populacional a fim de identificar estratégias potenciais de manejo dessa praga. O objetivo deste trabalho foi estudar o comportamento de adultos de P. cuyabana. O estudo foi realizado em laboratório,

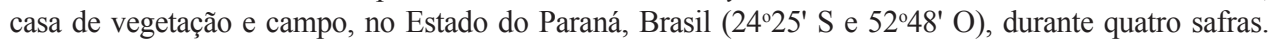
Os resultados obtidos demonstraram que: a) os adultos de P. cuyabana têm um vôo sincronizado durante um curto período quando ocorre o acasalamento e reprodução; b) os adultos tendem a se agregar em sítios específicos para o acasalamento; c) a maioria dos adultos deixa o solo em noites alternadas; d) a escolha do sítio de acasalamento e oviposição é feita pelas fêmeas antes da cópula; após a cópula os adultos não voam e se enterram em locais próximos; e) as fêmeas que ingerem folhas após o acasalamento ovipositam mais que as fêmeas que não se alimentam; f) espécies vegetais como girassol (Helianthus annuus) e Crotalaria juncea são importantes fontes de alimento para os adultos.
\end{abstract}

Termos para indexação: Glycine max, coró, planta hospedeira, postura, praga das plantas.

\section{Introduction}

Since 1985, a complex of white grub larvae has caused damage to soybean (Glycine max) crops in a

(1) Accepted for publication on October 25, 2002.

(2) Embrapa-Centro Nacional de Pesquisa de Soja, Caixa Postal 231, CEP 86001-970 Londrina, PR, Brazil. E-mail: lenita@cnpso.embrapa.br

(3) Universidade Estadual de Campinas, Instituto de Biologia, Dep. de Zoologia, CEP 13081-970 Campinas, SP, Brazil. E-mail: alika@unicamp.br number of regions in Brazil. Soybean was introduced in the state of Paraná about 26 years ago and since then has become one of the most important crops in Brazil.

One of the principal white grub pest in soybean is Phyllophaga cuyabana (Moser). This species may have evolved under environmental conditions found in the borders between the Cerrado and the Atlantic Forest and became widespread with monoculture (Morón \& Rojas, 2001).

The genus Phyllophaga is mainly associated with dicotyledonous plants and references to its 
occurrence on monocotyledons and gymnosperms are rare (Morón, 1986).

In Mexico, adults of the Phyllophaga species have been collected from sugarcane, rice, maize, sorghum, onion, beans, potato, peanut and Acacia maizeigera. Adults have also been captured in tropical deciduous and evergreen forests (Deloya, 1993). Phyllophaga species lay isolated eggs in the soil and the larvae feed on roots (King, 1984; Forsheler \& Gardner, 1990; Santos, 1992). Adults emerge after sexual maturity, mate and may feed on leaves (Gruner, 1973; Gaylor \& Frankie, 1979; Potter, 1981). Complete life cycle of Phyllophaga species may last six months to four years (Morón, 1986).

P. cuyabana is a univoltine species and its complete development occurs underground. Adults leave the soil at night and fly mainly to mate, after which they return to the soil and remain buried 5 to $15 \mathrm{~cm}$ below the surface (Santos, 1992). Below ground development makes pest control difficult by conventional methods, such as chemical and biological insecticides, which highlights the need to understand its dispersion, reproduction, and population establishment behavior.

The objective of this work was to study the behavior of $P$. cuyabana adults.

\section{Material and Methods}

The studies were carried out in laboratory and greenhouse in Londrina, PR and in soybean fields of Boa Esperança and Juranda counties, PR, Brazil (24을 $\mathrm{S}$ and $52^{\circ} 48^{\prime} \mathrm{W}$ ), from October to December, during four seasons (92/93, 93/94, 94/95 and 95/96).

\section{Flight and mating behavior}

Between 1992 and 1995, field observations were performed during the activity period immediately after dusk by walking through transects of 20 to $100 \mathrm{~m}$ in soybean fields and the bordering vegetation, such as woods, tree lines (wind breaks), or maize fields surrounding the area. Behavior observations of adults were recorded (calling position, mating, feeding, walking, flying, immobility). Observations of mating and non-mating adults were conducted five nights per year in 1992 (88 adults), 1993 (75 adults), 1994 (97 pairs) and 1995 (250 adults), for five hours per night, beginning when the first adult left the soil. Specific observations on one mating or non-mating individual or couple were made to detail behavioral traits. Nocturnal population flight data were obtained during 11 nights by observing the first to the last adult flight.

In the field, adults were captured at mating periods, during the first night flight. A head lantern that did not affect behavioral patterns in previous tests was used during capture and nocturnal observations. Sometimes a pair continued to mate after having been captured. Santos (1992) also used lanterns in his study on $P$. cuyabana and also did not report effects of this light on adults. Each year the beginning of the flights was monitored by taking weekly soil samples during the month of October, complemented with daily nocturnal observations during the last week. The method was chosen based on previous studies by Santos (1992) and Oliveira (1997) who found that adults go through a sexual maturation period of up to 15 days in soil chambers during October.

Adults collected in the field were studied in greenhouse conditions $\left(230 \mathrm{~m}^{2}, 23.7 \pm 2^{\circ} \mathrm{C}\right.$, air relative humidity $=84.7 \pm 4.8 \%$ ). The beetles ( 500 pairs $)$ were released in a greenhouse containing 1,300 potted soybean plants, and their behavior was recorded during six nights. Individual flight behavior was assessed every night, by placing white correction fluid on different parts of the elytrum, after landing, in order to distinguish between days.

\section{Feeding and oviposition in the laboratory}

Three laboratory trials were carried out using adults collected in the field during the first night-flight at Boa Esperança.

Two experiments (no choice and double-choice female feeding tests) using a completely random experimental design were performed to test five foods: soybean (Glycine max), maize (Zea mays), sunflower (Helianthus annuus), crotalaria (Crotalaria juncea), and cotton (Gossypium hirsutum) leaves. In the first experiment, insects had no food choice. In the second one, insects could choose between two plants. On both experiments, each plot consisted of one acrylic box $(10 \times 10 \times 3 \mathrm{~cm})$, maintained in a growth chamber at $25 \pm 2^{\circ} \mathrm{C}$ and at a 14 -hour photophase. Each box contained one P. cuyabana female, moist soil and leaf discs with a known area, obtained from leaves previously washed and dried on filter paper. Leaf discs were changed daily and the remaining leaf area was measured. In order to record the decrease of leaf area due to moisture loss, control leaf discs were maintained under the same conditions. The area of the control leaves was measured at the same time as the remaining leaves after female feeding. All leaf area evaluations were performed using a leaf area meter (LICOR, model LI-300) equipped with a photoelectric cell. 
In the no-choice experiment (the first experiment), conducted with 30 females (replicates) per treatment, for six days, two discs of a single plant species (soybean, maize, sunflower, C. juncea or cotton) were offered to each female. In the dual-choice experiment (the second experiment), conducted for ten days with 20 replicates per treatment, soybean leaves and one of the test plant species were simultaneously offered to each female (e.g., one soybean leaf disc and one maize leaf disc). In the dual-choice experiment, the proportion of soybean consumption was evaluated, dividing the soybean leaf area ingested by the total ingested leaf area of the two plant species offered to the female, in each acrylic box. The expected proportion of consumption, assuming no preference for any plant species, was 0.50 . In other words, it was expected that the female should ingest equal quantities of each plant species.

Laboratory test of feeding and oviposition behavior (the third experiment) were based on daily observation of 60 pairs of $P$. cuyabana. Each pair was put in a cage (a two-liter acrylic pot covered with a net) containing moist soil and soybean leaves with the petioles wrapped in wet cotton. The pots were maintained at $25 \pm 2^{\circ} \mathrm{C}$ in the laboratory with natural lighting (windows), without control of photoperiod.

Data were submitted to analysis of variance (ANOVA) using a general linear model (GLM). When the ANOVA indicated a significant effect of treatments at $5 \%$ of probability, the means were compared by Tukey, or $t$ test, according to the number of comparisons. In cases where few or no replicates were available, frequencies were compared with $\chi^{2}$ test.

\section{Results and Discussion}

\section{Flight and mating behavior}

In all years, appearance of the adults on the soil surface occurred shortly after sunset. Flight activity of $P$. cuyabana occurred during November and December, for a period of $48.3 \pm 0.97$ days. The adults did not fly on rainy nights.

Adults flew from the soil at the beginning of the night to feed and mate. The same behavior pattern was observed in other species of the family Scarabaeidae, such as Holotrichia parallela (Yoshioka \& Yamasaki, 1983) and Maladera matrida (Harari et al., 1994).

Adults were more abundant on the upper half of the plants and on conspicuous landscape features, such as trees in the middle of the field, where concentrations of hundreds of individuals could be observed. On one night, when the population size was evaluated on a line of trees, a population density of 120 adults/linear meter was observed on the vegetation canopy. Adult aggregations were also observed on soybean plants. These sites were marked. Subsequent observations showed patches of damaged plants. Adult aggregations have also been reported for species of Scarabaeidae e.g., Popillia japonica (Ladd, 1970), Cyclocephala spp. (Potter, 1980), and Cotinis nitida (Domek \& Johnson, 1990).

In the genus Phyllophaga, females usually release a sexual pheromone, which in some species is produced when insects are still in the soil, leading to concentrations of males at certain sites on the soil surface, waiting for the appearance of a female (Morón, 1986).

Adults do not leave the soil at the same time. The mean population flight duration was $40.3 \pm 2.40$ minutes ( 30 to 60 minutes; $n=11$ nights). After this period, the majority of adults were observed on plants or other prominent sites, in pairs or isolated, practically motionless. Adults were found on the crop canopy up to five hours from the start of flight activity, although after two hours, most of the insects were back on the soil surface (Figure 1).
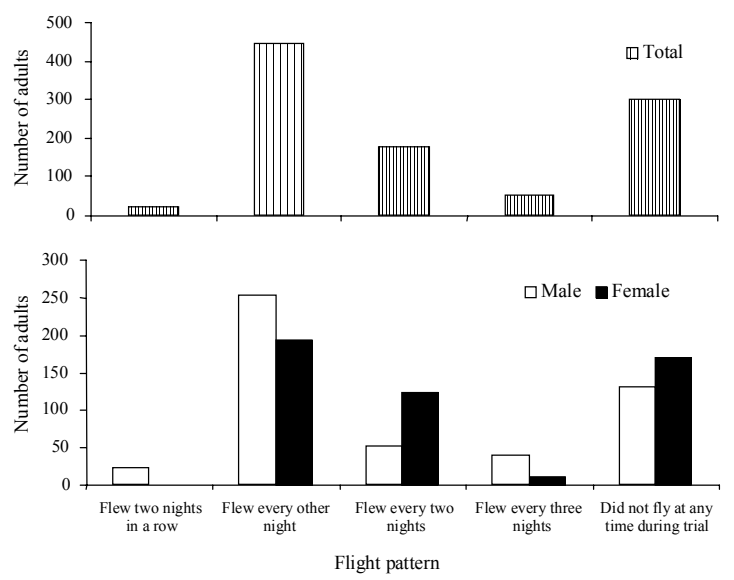

Figure 1. Pattern of flight activity of adults of Phyllophaga cuyabana outside of soil in the greenhouse, during four nights of observation ( $\mathrm{n}=500$ pairs). All the adults flew in the field the night before the greenhouse trial. Difference between males and females was significant by $\chi^{2}$ test at $5 \%$ of probability. 
In areas with no soybean, adults grouped in patches on weeds located within or at the edges of the field, and on the surrounding crops (soybean and maize). Females were observed in these areas, soon after leaving the soil, flying about $20 \mathrm{~m}$ in a straight trajectory before landing on the plants.

In trials with 40 pairs placed in small cages, Oliveira et al. (1996) observed that adults fly 5 to 10 times throughout their life cycle, but the frequency of their aerial behavior was not determined. Studies were thus conducted with 500 pairs, observed during one night in the field and four nights in the greenhouse $\left(230 \mathrm{~m}^{2}\right)$, showing that the behavior flight pattern is variable but confirming that the majority $(44.7 \%)$ of adults flew out on alternate nights (Figure 2), but more males flew out on alternate nights (50.8\%) than females (38.6\%). However, $30.2 \%$ of the adults did not fly at all in greenhouse (Figure 2), although they flew in the field site before they were collected. The number of females that did not flight in greenhouse was significantly greater than the number of males $\left(\chi^{2}=5.298\right.$, significant at $0.02 \%$ probability).
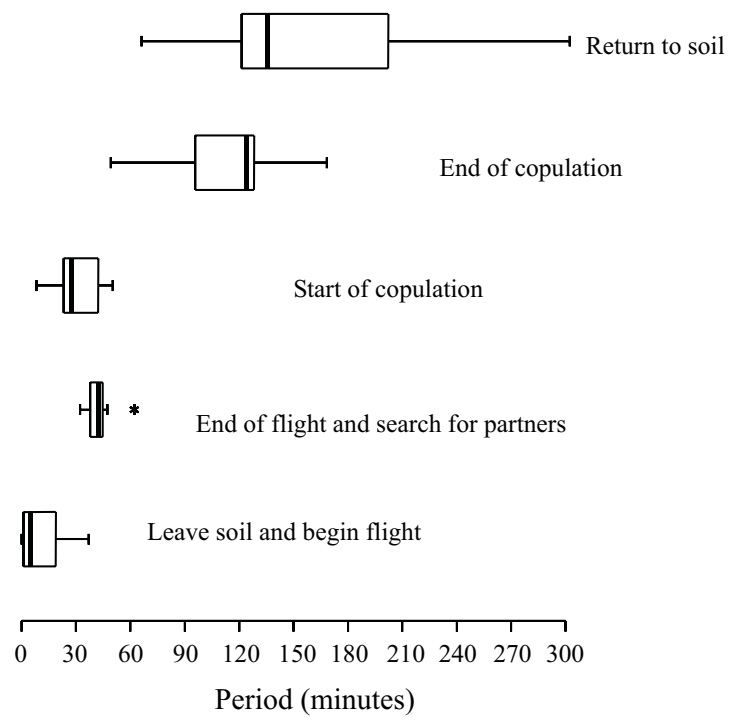

Figure 2. Activity period after dusk of Phyllophaga cuyabana adults outside of soil, in the field. Median(I), interquartile range $(\square)$, minimal and maximal value $(\vdash-1)$, outlier $(*)$.

\section{Courtship behavior and mating in the field}

Females left the soil and flew 10 to $30 \mathrm{~cm}$ above the crop canopy (average canopy height of $0.50 \mathrm{~m}$ ), landing immediately on the top of the plants or on other prominent sites in the area. Soon after landing, females raised their metathoraxic legs, exposing the terminal segment of the abdomen and the yellow glandular region, which probably releases a sexual pheromone. After landing, the females generally remained immobile until contacted by a male. Five percent of these females observed ( 80 observations), however, continuously scratched the yellow gland with their legs, a behavior also observed at the end of copulation.

On average, females remained in this calling position for $3.5 \pm 1.05$ minutes ( $\mathrm{n}=12$ observations) before being approached by a male. The longest calling time observed was 12 minutes, although in this case no copulation occurred. On three occasions, females in the calling position were observed on top of copulating pairs, a phenomenon also reported by Santos (1992). H. parallela females have been observed exhibiting similar behavior, exposing an abdominal gland which excreted a sexual pheromone for a period no longer than 15 minutes (Leal et al., 1992). Biological activity of the chemical extracts of $P$. cuyabana female abdominal glands was tested in the laboratory and in the field, showing pheromone activity (Oliveira, 1998).

Soon after leaving the soil, males tended to walk around in a circle (approximately $50 \mathrm{~cm}$ radius), before flying first vertically and then horizontally at about 0.30 to $5 \mathrm{~m}$ above the soil, depending on the height of the surrounding plants or other structures in the area. The longest distance observed in the field for a continuous flight in the same direction was about 15 to $20 \mathrm{~m}$. Males would fly at random over the area, sometimes in a zigzag pattern, with the lamellae of their antenna totally expanded, probably to detect the pheromone of a potential mate.

Contact with females was made with intense wing flapping. Next, the male would alight on top of the female and immediately attempt copulation. A rapid recognition sequence was observed, attributed to movements of the male antennae touching the female's head and prothorax. The occurrence of several males flying in circles over a female in the calling position was common. Mating usually 
occurred within plant foliage. Males ignored females that were not in the calling position, even if they were at a very short distance, suggesting that visual cues were not important. This behavior, characterized as courtship, took a mean time of $1.8 \pm 0.27$ minutes.

\section{Copulation and post-copulation behavior}

After initiating copulation, the male would attach to the female, maintaining a perpendicular position in relation to the female. During copulation, the pairs remained practically immobile, but eventually a small movement by the male could be observed, and on rare occasions the female was observed walking, pulling the male along. Males trying to separate copulating pairs were also observed (3\% of observed pairs).

After copulation, which in the field took a mean time of $83.9 \pm 4.20$ minutes, occurring only once each night, males and females remained static on the plant for up to 30 minutes. Afterwards, they walked down slowly with occasional intermediate stops, to the soil surface, where they would move in different directions, sometimes in circles. Both males and females buried themselves in the soil near the copulation site, although for the male, the time interval between copulation and return to the soil tended to be shorter (Table 1). On some occasions,

Table 1. Time between the end of copulation of Phyllophaga cuyabana adults, in the field, and their return to the soil (return time), time on the soil surface and the distance between the mating site and the point of entry into the soil ${ }^{(1)}$.

\begin{tabular}{lccc}
\hline Parameter & $\begin{array}{c}\text { Mean } \pm \text { standard } \\
\text { error }\end{array}$ & $\begin{array}{c}\text { Variation } \\
\text { interval }\end{array}$ & Observations \\
\hline Female & $68.9 \pm 8.0^{\text {ns }}$ & $(10-88)$ & 12 \\
Male & $48.3 \pm 5.6$ & $(20-143)$ & 13 \\
\hline Mean & $59.2 \pm 5.4$ & $(10-143)$ & 25 \\
\hline \multicolumn{5}{c}{ Return } \\
Female & $17.1 \pm 2.0 \mathrm{a}$ & $(9-30)$ & 10 \\
Male & $6.9 \pm 1.7 \mathrm{~b}$ & $(1-15)$ & 10 \\
\hline Mean & $12.0 \pm 1.7$ & $(1-30)$ \\
\hline \multicolumn{5}{c}{ Return distance $(\mathrm{cm})$} \\
Female & $71.6 \pm 17.2^{\text {ns }}$ & $(15-156)$ \\
Male & $63.8 \pm 11.4$ & $(18-198)$ & 12 \\
\hline Mean & $67.3 \pm 9.9$ & $(15-198)$ \\
\hline (1) Means followed by the same letter within a column (comparing male and \\
female) did not differ significantly by t test at 5\% of probability. \\
ns Not-significant by t test at 5\% of probability.
\end{tabular}

males simply dropped to the soil, burying themselves immediately, while females moved on the soil surface, probably searching for a suitable site for burying and oviposition.

Under greenhouse conditions, Santos (1992) found that adults of both sexes copulated several times during the reproduction period, but only once each night. Under confinement conditions, females copulated with the same male more than once, but not on the same night. He also found that some females in the laboratory laid eggs immediately after the first copulation, while others only laid their eggs after copulating twice. Oliveira et al. (1996) found that the mean number of mating was 3.8 and 3.9 for males and females, respectively, with only a single copula per pair per night.

\section{Feeding and oviposition}

In the field, a number of females were observed to feed on leaves of soybean, maize, sunflower, Crotalaria juncea, C. spectabilis, Cinamon sp. and Senecio brasiliensis. Females consumed small amounts. No males were seen feeding in the field or in the laboratory, while $70 \%$ of the females were observed feeding on soybean leaves in the laboratory (Oliveira et al., 1996). Santos (1992) also observed females feeding during and after copulation.

The amount of leaves ingested by females varied according to plant species, being higher with C. juncea and sunflower. Female feeding frequency also differed among plant species, with only $36.7 \%$ of the females feeding on cotton leaves (Table 2). In a dual-choice situation, females consumed proportionally larger amounts of $C$. juncea and sunflower leaves than soybean (Table 3 ), indicating that these plants were preferred hosts. When couples were released in cages with different plant species, with only one plant type per cage, Oliveira (1997) found that females laid more eggs in cages with sunflower or $C$. juncea than maize, Crotalaria spectabilis or cotton.

The ingestion of leaves by females, even in small amounts, may be associated with supplementary energy needs for reproduction, although, in the laboratory, females that never fed also produced fertile eggs. About $53 \%$ of the females that laid eggs fed at least once after copulation and the majority of these 
females oviposited more than once and laid more eggs than those that oviposited but never fed (Table 4). About $12 \%$ of the females neither ate, nor oviposited. Only $0.5 \%$ of the females that fed and oviposited ingested leaves prior to the first oviposition, and none of these did so after the final oviposition period.

Table 2. Leaf consumption (mean \pm standard error during six days) by females of Phyllophaga cuyabana on different plant species, in the laboratory ${ }^{(1)}$.

\begin{tabular}{lcc}
\hline Plant species & $\begin{array}{c}\text { Females feeding } \\
(\%)\end{array}$ & $\begin{array}{c}\text { Leaf consumption } \\
\left(\mathrm{cm}^{2}\right)\end{array}$ \\
\hline Crotalaria juncea & 80.00 & $13.23 \pm 1.29 \mathrm{a}$ \\
Helianthus annuus & 66.67 & $12.56 \pm 1.47 \mathrm{a}$ \\
Glycine max & 57.67 & $5.45 \pm 1.50 \mathrm{~b}$ \\
Zea mays & 70.00 & $4.19 \pm 0.74 \mathrm{~b}$ \\
Gossypium hirsutum & 36.67 & $3.05 \pm 0.68 \mathrm{~b}$ \\
\hline
\end{tabular}

(1)Means followed by the same letter within a column were not significantly different by the Tukey test at 5\% of probability. (2)There were differences in the frequency of females that fed on several plants $\left(\chi^{2}=11.40 ; \mathrm{DF}=4\right.$ $\mathrm{P}=0.022)$. The test of $\chi^{2}$ was performed with real frequency of females that fed or did not feed ( $\mathrm{n}=30$ females/treatment).

\section{Agroecological significance}

Large numbers of $P$. cuyabana adults left the soil near the sites chosen by females for mating and such behavior increased the chances of mating. A physiological response may be associated to synchronized flight behavior of the $P$. cuyabana. The $P$. cuyabana flying period always coincides with soybean planting and initial growth periods. This behavior has been observed for several years (Oliveira, 1997) and can be predicted, suggesting that rapid selection can occur over time, synchronizing host plant availability for offspring with insect reproduction. Soybean has become the main crop in the region and $P$. cuyabana has adapted to this easy and abundant resource. In the last 15 years, soybean has substituted the native forests as $P$. cuyabana's domain; the forests, where it once thrived, have been reduced to less than $3 \%$ of the region's vegetation (Oliveira, 1997).

Some characteristics of the behavior of adult $P$. cuyabana, shown in this paper, confirm that the

Table 3. Leaf area consumed (mean \pm standard error) by Phyllophaga cuyabana females that fed on several plant species in a dual choice situation, in the laboratory ${ }^{(1)}$.

\begin{tabular}{lrccc}
\hline \multirow{2}{*}{$\begin{array}{c}\text { Soybean and test plant } \\
\text { offered }\end{array}$} & \multicolumn{3}{c}{ Leaf area consumed $\left(\mathrm{cm}^{2}\right)$} & \multirow{2}{*}{$\begin{array}{c}\text { Soybean } \\
\text { proportion }\end{array}$} \\
\cline { 2 - 4 } & \multicolumn{1}{c}{ Total } & Soybean & Test plant & $0.70 \pm 0.12 \mathrm{a}$ \\
Soybean and cotton & $17.63 \pm 5.19 \mathrm{a}$ & $10.93 \pm 4.27$ & $6.70 \pm 3.25$ & $0.52 \pm 0.11 \mathrm{ab}$ \\
Soybean and soybean & $12.42 \pm 2.06 \mathrm{a}$ & $5.91 \pm 1.70$ & $6.52 \pm 2.05$ & $0.30 \pm 0.11 \mathrm{bc}$ \\
Soybean and maize & $9.25 \pm 3.31 \mathrm{a}$ & $3.49 \pm 2.22$ & $5.76 \pm 2.96$ & $0.11 \pm 0.05 \mathrm{c}$ \\
Soybean and $C$. juncea & $18.06 \pm 3.23 \mathrm{a}$ & $1.99 \pm 1.24$ & $16.08 \pm 2.54$ & $0.15 \pm 0.07 \mathrm{c}$ \\
Soybean and sunflower & $15.06 \pm 3.61 \mathrm{a}$ & $1.71 \pm 0.96$ & $13.35 \pm 3.42$ & \\
\hline
\end{tabular}

${ }^{(1)}$ Means followed by the same letter within a column did not differ significantly by Tukey test at $5 \%$ of probability; $\mathrm{n}=20$ females/treatment. ${ }^{(2)}$ Difference was observed by $\mathrm{F}$ test, but the means were not significantly different by Tukey test at $5 \%$ of probability.

Table 4. Number of Phyllophaga cuyabana females that laid eggs once or more, number of eggs and oviposition period for females that fed or did not feed after mating, in the laboratory ${ }^{(1)}$.

\begin{tabular}{lccccc}
\hline Feeding $^{(2)}$ & Ovipositing & $\begin{array}{c}\text { Females } \\
\text { that laid } \\
\text { eggs once }\end{array}$ & $\begin{array}{c}\text { Females } \\
\text { that laid eggs } \\
\text { more than once }\end{array}$ & Eggs/female & $\begin{array}{c}\text { Oviposition } \\
\text { period (days) }\end{array}$ \\
\hline Yes & Yes & 28 & 22 & $18.96 \pm 2.22 \mathrm{a}$ & $8.26 \pm 0.87^{\text {ns }}$ \\
No & Yes & 25 & 16 & $12.48 \pm 2.32 \mathrm{~b}$ & $6.95 \pm 0.95$ \\
No & No & 7 & - & - & - \\
\hline Total & & 60 & 38 & - & - \\
\hline
\end{tabular}

${ }^{(1)}$ Means followed by the same letter within a column did not differ significantly by $\mathrm{t}$ test at $5 \%$ of probability; $\mathrm{n}=60$ females. ${ }^{(2)} \mathrm{At}$ least once after mating regardless of the amount of food ingested. ${ }^{(3)}$ Difference was significant $\left(\chi^{2}=5.249 ; \mathrm{DF}=1 ; \mathrm{P}=0.022\right) .{ }^{(4)}$ Not-significant by $\mathrm{t}$ test at $5 \%$ of probability. 
control of the adult phase in its life-cycle is little viable, since the alternating nocturnal activity of different individuals of the population, the low mobility of these adults when they are above-ground, and the low feeding rates, decrease the feasibility of chemical (insecticide) control. Nevertheless, localized control could be an alternative, considering that the aggregated behavior associated with food preference may be used to attract adults to specific sites with trap crops. The use of preferential food sources such as sunflower, in which ingesting by females is greater, could also potentially increase the action of some types of chemical or biological insecticides that act through ingestion.

\section{Conclusions}

1. Phyllophaga cuyabana adults have a synchronized short-flight period when mating and reproduction occurs.

2. Adults tend to aggregate in specific sites for mating.

3. The majority of adults left the soil on alternate nights. Females that fed on leaves after mating, oviposited more eggs than females that had not fed.

4. Helyanthus annuus (sunflower) and Crotalaria juncea are food sources for females.

\section{Acknowledgements}

To Sérgio H. Silva and Youssef A. Mazlum for their kind assistance; to George G. Brown for helping with the English text; to José Erivaldo for helping with statistic analyses; to Capes for a doctoral fellowship to the senior author.

\section{References}

DELOYA, C. El genero Phyllophaga Harris en Cuernavaca, Morelos, México (Coleoptera: Melolonthidae, Melolonthinae). In: MORÓN, M. A. (Ed.). Diversidad y manejo de plagas subterráneas. Xalapa: Sociedad Mexicana de Entomología/Instituto de Ecología, 1993. p. $39-54$

DOMEK, J. M.; JOHNSON, D. T. Inhibition of aggregation behavior in the green June beetle (Coleoptera: Scarabaeidae) by antibiotic treatment of food substrate.
Environmental Entomology, College Park, v. 19, p. 995-1000, 1990.

FORSHELER, B. T.; GARDNER, W. A. A review of the scientific literature on the biology and distribution of genus Phyllophaga (Coleoptera: Scarabaeidae) in Southeastern United States. Journal of Entomological Science, Griffin, v. 25 , p. 628-651, 1990.

GAYLOR, M. J.; FRANKIE, G. W. The relationship of rainfall to adult flight activity and of soil moisture to oviposition behavior and egg and first instar survival in Phyllophaga crinita. Environmental Entomology, College Park, v. 8, p. 591-594, 1979.

GRUNER, L. Recherches sur le comportement, au cours de sa vie imaginale de Phyllophaga pleei Bl. (Coleoptera: Scarabaeidae). Annales de Zoologie-Ecologie Animale, Versailles, v. 5, p. 385-424, 1973.

HARARI, A. R.; BEM-YAKIR, D.; ROSEN, D. Mechanism of aggregation behavior in Maladera matrida Argaman (Coleoptera: Scarabaeidae). Journal of Chemical Ecology, New York, v. 20, p. 361-371, 1994.

KING, A. B. S. Biology and identification of white grubs (Phyllophaga) of economic importance in Central America. Tropical Pest Management, London, v. 30, n. 1, p. 36-50, 1984.

LADD, T. L. Sex attraction in the Japanese beetle. Journal of Economic Entomology, College Park, v. 63, p. 340-344, 1970.

LEAL, W. S.; MATSUYAMA, S.; KUWAHARA, Y; WAKAMURA, S.; HASEGAWA, M. An amino acid derivative as the sex pheromone of scarab beetle. Naturwissenschaften, Berlin, v. 79, p. 184-185, 1992.

MORÓN, M. A. El genero Phyllophaga en México: morfología, distribución y sistemática supra-específica (Insecta: Coleoptera). México: Instituto de Ecología, 1986. 341 p. (Publicación, 19).

MORÓN, M. A.; ROJAS, C. V. Las especies de Phyllophaga en Brasil (Coleoptera: Melolonthidae; Melolonthinae). In: REUNIÃO SUL-BRASILEIRA SOBRE PRAGAS DE SOLO, 8., 2001, Londrina. Anais... Londrina: Embrapa-CNPSo, 2001. p. 217-221. (Documentos, 172).

OLIVEIRA, L. J. Ecologia comportamental e de interações com plantas hospedeiras em Phyllophaga cuyabana (Moser) (Coleoptera: Melolonthidae, 
Melolonthinae) e implicações para o seu manejo em cultura de soja. 1997. 148 f. Tese (Doutorado em Ciências: Ecologia) - Universidade Estadual de Campinas, Campinas, 1997.

OLIVEIRA, L. J. Identificação do feromônio sexual e efeitos no comportamento do besouro Phyllophaga cuyabana. In: EMBRAPA. Centro Nacional de Pesquisa de Soja (Londrina, PR). Resultados de pesquisa de soja 1997. Londrina, 1998. p. 69-70. (Documentos, 118).

OLIVEIRA, L. J.; SANTOS, B.; PARRA, J. R. P.; AMARAL, L. B. do; MAGRI, D. C. Ciclo biológico de Phyllophaga cuyabana (Moser) (Scarabaeidae: Melolonthinae). Anais da Sociedade Entomológica do Brasil, Londrina, v. 25, n. 3, p. 433-439, 1996.

POTTER, D. A. Flight activity and sex attraction of northern and southern masked chafers in Kentucky. Annals of the Entomological Society of America, Lanham, v. 73, p. 414-417, 1980.

POTTER, D. A. Seasonal emergence and flight of northern and southern masked chafers in relation to air and soil temperature and rainfall patterns. Environmental Entomology, College Park, v. 10, p. 793-797, 1981.

SANTOS, B. Bioecologia de Phyllophaga cuyabana (Moser 1918) (Coleoptera: Scarabaeidae), praga do sistema radicular da soja [Glycine max (L.) Merrill, 1917]. 1992. 111 f. Dissertação (Mestrado em Ciências: Entomologia) - Escola Superior de Agricultura Luiz de Queiroz, Piracicaba, 1992.

YOSHIOKA, K.; YAMASAKI, Y. Ecology of Lachnosterna morose - I: behavior of the time of appearance on the ground and oviposition of adult insects. Japanese Journal of Applied Entomology and Zoology, Tokyo, v. 27, p. 52-54, 1983. 